УДК 581.5+581.19

О. М. Василюк, А. Ф. Кулік

Дніпропетровський національний університет ім. Олеся Гончара

\title{
АКТИВНІСТЬ ФЕРМЕНТІВ ПЕРЕАМІНУВАННЯ В ЛИСТКАХ SAMBUCUS NIGRA В УМОВАХ ПІДВИЩЕНОЇ МІНЕРАЛІЗАЦЇ̈
}

Досліджено вплив екзогенного чинника - сульфату магнію у спектрі концентрацій 0,5-2,5 г/л на активність трансаміназ аспартатамінотрансферази (АсАТ, КФ 2.6.1.1) і аланінамінотрансферази (АлАТ, КФ 2.6.1.2) у листках живців Sambucus nigra L. в умовах модельного досліду. Показано кореляційні зв'язки між величиною засолення та динамікою активності ферментів переамінування.

Е. М. Василюк, А. Ф. Кулик

Днепропетровский национальный университет им. Олеся Гончара

\section{АКТИВНОСТЬ ФЕРМЕНТОВ ПЕРЕАМИНИРОВАНИЯ \\ В ЛИСТЬЯХ SAMBUCUS NIGRA В УСЛОВИЯХ ПОВЫШЕННОЙ МИНЕРАЛИЗАЦИИ}

\begin{abstract}
Исследовано воздействие экзогенного фактора - сульфата магния в спектре концентраций 0,5-2,5 г/л на активность трансаминаз аспартатаминотрансферазы (АсАТ, КФ 2.6.1.1) и аланинаминотрансферазы (АлАТ, КФ 2.6.1.2) в листьях Sambucus nigra L. в условиях модельного эксперимента. Показаны корреляционные связи между величиной засоления и динамикой активности ферментов переаминирования.
\end{abstract}

\author{
O. M. Vasylyuk, A. F. Kulik \\ Oles' Honchar Dnipropetrovsk National University
}

\section{TRANSAMINATION ENZYMES ACTIVITY IN THE LEAVES OF SAMBUCUS NIGRA UNDER THE HIGH MINERALIZATION}

The aspartate aminotransferase (AsAT, EC 2.6.1.1) and alanine aminotransferase (AIAT, EC 2.6.1.2) activities in the leaves of Sambucus nigra $\mathrm{L}$. under the magnesium sulfate $(0.5-2.5 \mathrm{~g} / \mathrm{l})$ influense as an exogenous factor in a model experiment are analysed. The correlation between minaralization level and transaminases activities in the leaves are presented.

\section{Вступ}

В умовах росту промислового навантаження збільшується кількість полютантів, що забруднюють навколишнє середовище. Складові біоти отримують стресові навантаження та формують механізми відповіді у боротьбі за виживання. Техногенне забруднення навколишнього середовища в локальних масштабах відповідає високому рівню екологічно значимого чинника, який лімітує розвиток багатьох видів організмів. Існує необхідність говорити про деяку неспецифічність дії полютантів. Різні за хімічним складом емісії промислових підприємств, шахт, викидні гази автотранспорту, агротехнічні засоби, різні види забруднення акваторій викликають подібні симптоми 
ушкодження. Вивчення впливу стресових факторів навколишнього середовища на процеси метаболізму у фіто-, зоо-, мікробоценозах, едафотопах і зміна активності ферментних систем дозволяє з'ясувати роль ензимів у формуванні стійкості компонентів біоти до екзогенного стресу антропогенного $[5 ; 10 ; 12 ; 16 ; 21 ; 24 ; 32 ; 34]$ та природного походження $[14 ; 15 ; 17-20 ; 30 ; 35]$. Недостатня зволоженість і високі температури степового Придніпров'я ускладнюють екологічну ситуацію даного регіону, тому малі річки зазнають значної трансформації: занесення, замулення, у результаті чого відбувається активне заростання очеретом південним (Phragmities australis (Cav.)), змінюється склад та структура гідробіоценозів [3].

Основний метод відновлення гідрологічного режиму річок - механічне розчищення русел, а основний метод боротьби з надмірним заростанням річок після їх розчищення - формування тіньової структури у прибережній зоні шляхом створення берегових лісосмуг по урізу води [3].

Висока мінералізація річок Степу унеможливлює використання широкого спектру деревних культур як лісосмуг, що сприяє визначенню відповідних видів рослин. Так обрано вербу білу (Salix alba L.) та бузину чорну (Sambucus nigra L.) як види з широкою екологічною амплітудою до різних екологічних факторів, у тому числі різного ступеня мінералізації.

Підвищена мінералізація викликає стресове навантаження рослинного організму, що проявляється зміною напряму метаболізму (фотосинтез, дихання, мінеральне живлення, водний режим, синтез амінокислот), біосинтез специфічних стресових білків [15] за умов холодового, теплового шоку, водного дефіциту тощо, підтримання гомеостазу та гормонального статусу як неспецифічного відгуку на дію екзогенного чинника. За даних умов змінюється напрям азотного метаболізму, що впливає на нормальний перебіг анаболічних процесів, процесів білкового синтезу. Ферменти переамінування аспартатамінотрансфераза (АсАТ) та аланінамінотрансфераза (АлАТ) сприяють формуванню неспецифічних механізмів адаптації організмів до стресів $[1 ; 2 ; 6-9 ; 11 ; 25-$ $29 ; 31 ; 33 ; 34]$.

Мета даної роботи - оцінити активність аспартатамінотрансферази (АсAТ, КФ 2.6.1.1) та аланінамінотрансферази (АлАТ, КФ 2.6.1.2) у листках живців Sambucus nigra L. в умовах модельного досліду.

Ці ензими - частина ферментативної системи, за допомогою якої утилізується первинний продукт фотосинтезу аспартатної групи $C_{4}$-рослин - аспартат, який синтезується у мезофілі листка. За допомогою АсАТ за присутності коферменту піридоксальфосфату, похідного вітаміну $B_{6}$, в обкладинці листків відбувається декарбоксилювання аспартату з утворенням щавлевооцтової кислоти (ЩОК), яка за участю малатдегідрогенази перетворюється на малат. Малат вступає в наступну реакцію за участю малик-ензиму: відбувається утворення піровиноградної кислоти (ПВК) та вуглекислого газу. Існує думка, що піруват, після амінування за участі АлАТ, а також за присутності коферменту піридоксальфосфату, повертається до мезофілу, де дезамінується за участі цього ж ферменту.

\section{Матеріал і методи досліджень}

Тест-об'єкт дослідження - Sambucus nigra L. - невибаглива та розповсюджена рослина, яка поряд із Salix alba L. відрізняється непоганим укоріненням і може використовуватись для утворення насаджень по урізу води на берегах малих річок степового Придніпров'я. $S$. nigra - це гіллястий кущ або невелике (5,0-5,5 м заввишки) деревце родини Adoxaceae із світло-бурою тріщинуватою корою. Пагони буруваті, всередині 
містять широку, білу, м’яку серцевину. Деревина бузини жовта або біла, легка, блискуча. Листки 35 см завдовжки, супротивні, непарноперисті. S. nigra росте в підліску листяних і мішаних лісів, по чагарниках, на лісових порубах, узбіччі лісових доріг, на узліссях. Поширена майже по всій Україні, придатна для живоплотів і поодиноких насаджень. Уводиться як підлісок у грунтозахисних протиерозійних насадженнях [13].

Живці вкорінювали у водних розчинах за такою схемою: № 1 - контроль (вода дистильована); № 2, 3, 4, 5 та 6 - розчин $\mathrm{MgSO}_{4} \cdot 3 \mathrm{H}_{2} \mathrm{O}(0,5,1,0,1,5,2,0$ та 2,5 г/л відповідно). Концентрацію розчинів забезпечували з урахуванням водності солі. Повторність дослідів триразова, по 30 живців у кожному варіанті досліду. Використання магнійумісної солі для даного досліду цікаве також у зв'язку з тим, що саме цей метал поєднує між собою 4 пірольних кільця хлорофілів. Відбувається поєднання між собою біохімічних процесів (фотосинтез і робота ферментів АлАТ та АсАТ, які є частиною ферментативної системи, за допомогою якої утилізується первинний продукт фотосинтезу).

Унаслідок переамінування за участі АлАТ, яка каталізує перенесення аміногрупи від аланіну на $\alpha$-КГК, утворюються глютамінова кислота та ПВК. Внаслідок переамінування за участі АсAТ, яка каталізує перенесення аміногрупи від аспарагінової на $\alpha$-КГК, утворюється глютамінова кислота та ЩОК. Утворені в результаті реакції кетокислоти (ЩОК та ПВК) при внесенні 2,4-динітрофенилгідразину дають забарвлення (гідразони ЩОК та ПВК), ензиматичний процес зупиняється у лужному середовищі (гідразон піровиноградної кислоти утворюється за умов спонтанного декарбоксилювання оксалоацетату, має більшу оптичну густину).

Загальні активністі ферментів переамінування АсАТ та АлАТ розраховували методом В. В. Польового та Г. Б. Максимова, виражали в нМ ПВК/мл екстракту за секунду (X). Оптичну щільність забарвлених сполук фіксували на спектрофотометрі Specord UV VIS при довжині хвилі 546 нм [4; 24]. Отримані результати оброблені статистично на $5 \%$ рівні значущості [23].

\section{Результати та їх обговорення}

Збільшення концентрації сульфату магнію викликає достовірне підвищення загальної активності АлАТ в листках $S$. nigra від $11 \%$ (варіант досліду з концентрацією солі 0,5 г/л) до 48 \% (варіант 1,5 г/л). Максимальна концентрація фітотоксиканта (2,5 г/л) сприяла суттєвому достовірному підвищенню даного показника на 31 \%. Таким чином, спостерігали процес загального підвищення активності АлАТ для всіх варіантів досліду, що доводить неспецифічність відповідної реакції білоксинтезувальної системи на дію екзогенних чинників. Отримані результати для даного об'єму вибірки достовірні на $5 \%$ рівні значущості $\left(t / t_{0,05}=1,96-6,15\right)$ та більшості варіантів - на $1 \%$ рівні значущості $\left(t / t_{0,01}=1,38-2,67\right)$. Для варіанта досліду 3 мінімальною концентрацією сульфату магнію різниця перебуває в межах випадкових коливань $\left(t / t_{0,05}<1, t / t_{0,01}<1\right)$, коефіцієнт варіації - від 1 до $6 \%$ (табл. 1$)$. Спостерігається позитивна кореляція $(r=0,68)$ між концентрацією солі магнію та активністю АлАТ.

Нарівні з визначенням активності АлАТ визначали й активність спорідненого ензиму АсАТ. Значення активностей АсАТ для всіх варіантів досліду нижче показників АлАТ в 1,5-2,0 рази для всіх варіантів досліду. Слід зазначити, що відбувається сполученість у роботі даних ензимів. Максимальна активність АсАТ зафіксована у варіанті 3 додаванням сульфату магнію в концентрації 2,0 г/л (3,31 нМ субстрату/мл·с), а мінімальна - у варіанті з концентрацією фітотоксиканта 2,5 г/л (на відміну від АлАТ). Тобто знижена активність одного ферменту змінюється підвищеною активністю іншо- 
іншого в даних варіантах досліду, що залежить від субстратного навантаження клітин рослинного організму, а також формування адаптаційних процесів, які не сприяють різкому виснаженню клітин і виражаються у вигідному почерговому реагуванні (коливання «підвищення - зниження») функціональних активностей споріднених ферментів. Максимальна активність АлАТ (у варіанті досліду із внесенням сульфату магнію в максимальній концентрації 1,5 г/л) пов'язана зі зниженою активністю АсАТ у даному варіанті досліду відносно інших. Значення показника загальної активності АсАТ достовірно від контролю відрізняється в усіх варіантах досліду на $5 \%$ рівні значущості $\left(t / t_{0,05}=3,21-10,24\right)$ та на $1 \%$ рівні значущості $\left(t / t_{0,01}=1,47-4,71\right)$, що доводить суттєвий вплив сульфату магнію на роботу АсАТ та відповідну реакцію білоксинтезувальної системи. Коефіцієнт варіації перебуває в межах 1,0-6,7 \%, точність досліду - до 4 \%. Кореляції між концентрацією чинника та активністю ферменту не спостерігається $(r=0,43)$ (табл. 2).

Таблиия 1

Вплив мінералізації на активність аланінамінотрансферази в листках Sambucus nigra L.

\begin{tabular}{|l|c|c|c|c|c|}
\hline \multicolumn{1}{|c|}{ Варіант досліду } & $X \pm m$ & $V$ & $M$ & $t / t_{0,05}$ & $t / t_{0,01}$ \\
\hline Контроль & $3,33 \pm 0,155$ & 1,81 & - & - & - \\
\hline $\mathrm{MgSO}_{4} \cdot 3 \mathrm{H}_{2} \mathrm{O}, 0,5$ г/л & $3,70 \pm 0,375$ & 4,05 & 111,1 & 0,92 & 0,39 \\
\hline $\mathrm{MgSO}_{4} \cdot 3 \mathrm{H}_{2} \mathrm{O}, 1,0$ г/л & $4,30 \pm 0,051$ & 0,48 & 129,1 & 6,15 & 2,67 \\
\hline $\mathrm{MgSO}_{4} \cdot 3 \mathrm{H}_{2} \mathrm{O}, 1,5$ г/л & $4,96 \pm 0,817$ & 6,64 & 148,9 & 1,96 & 0,85 \\
\hline $\mathrm{MgSO}_{4} \cdot 3 \mathrm{H}_{2} \mathrm{O}, 2,0$ г/л & $4,02 \pm 0,221$ & 2,21 & 120,7 & 3,19 & 1,38 \\
\hline $\mathrm{MgSO}_{4} \cdot 3 \mathrm{H}_{2} \mathrm{O}, 2,5$ г/л & $4,39 \pm 0,088$ & 0,81 & 131,8 & 6,11 & 2,64 \\
\hline
\end{tabular}

Примітки: $X$ - середнє, $m$ - вірогідний інтервал для $p=0,05 ; V$ - коефіцієнт варіації (\%), $M$ - дослід/контроль (\%), $t / t_{0,05}$ - критерій достовірної різниці між дослідом та контролем для $p<0,05, t / t_{0,01}-$ критерій достовірної різниці між дослідом та контролем для $p<0,01$.

Таблиия 2

Вплив мінералізації на активність аспартатамінотрансферази в листках Sambucus nigra L.

\begin{tabular}{|l|c|c|c|c|c|}
\hline \multicolumn{1}{|c|}{ Варіант досліду } & $X \pm m$ & $V$ & $M$ & $t / t_{0,05}$ & $t / t_{0,01}$ \\
\hline Контроль & $1,80 \pm 0,144$ & 3,21 & - & - & - \\
\hline $\mathrm{MgSO}_{4} \cdot 3 \mathrm{H}_{2} \mathrm{O}, 0,5$ г/л & $2,31 \pm 0,056$ & 0,98 & 178,3 & 3,28 & 1,52 \\
\hline $\mathrm{MgSO}_{4} \cdot 3 \mathrm{H}_{2} \mathrm{O}, 1,0$ г/л & $3,28 \pm 0,133$ & 1,64 & 182,2 & 10,24 & 4,71 \\
\hline $\mathrm{MgSO}_{4} \cdot 3 \mathrm{H}_{2} \mathrm{O}, 1,5$ г/л & $2,70 \pm 0,078$ & 1,16 & 150,0 & 6,24 & 2,88 \\
\hline $\mathrm{MgSO}_{4} \cdot 3 \mathrm{H}_{2} \mathrm{O}, 2,0$ г/л & $3,31 \pm 0,366$ & 4,45 & 183,8 & 10,09 & 4,65 \\
\hline $\mathrm{MgSO}_{4} \cdot 3 \mathrm{H}_{2} \mathrm{O}, 2,5$ г/л & $2,28 \pm 0,379$ & 6,68 & 126,6 & 3,21 & 1,47 \\
\hline
\end{tabular}

Примітки: див. табл. 1

Майже в усіх варіантах досліду спостерігали підвищення ферментативної активності трансфераз, що може сприяти активації процесів циклу Кребса (другий етап дихання), оскільки використовується піруват, утворений за участі АлАТ, прискорюються процеси утилізації первинного продукту фотосинтезу, що впливає на білковий обмін рослин і синтез стресових білків, які сприяють формуванню механізмів адаптаційного захисту рослинного організму.

\section{Висновки}

Ферменти переамінування АлАТ і АсАТ відіграють важливу роль в азотному, а отже, і білковому метаболізмі рослинного організму. Їх можна вважати маркерами неспецифічних адаптивних реакцій клітини за умови дії чинника нижче порогового. Pеагування на екзогенну дію поллютантів зміною активності трансаміназ (підвищення/зниження), характеризує стресове навантаження рослинної клітини. Достатня чут- 
ливість ферментів азотного обміну АлАТ і АсАТ дає можливість визначити біологічний відклик біохімічних систем на дію екзогенного чинника шляхом синтезу стресових білків, що сприяє розвитку загальних механізмів захисту рослин.

\section{Бібліографічні посилання}

1. Аминотрансферазна активація постачання субстратів у цикл Кребса за умов стресу у щурів з різною резистентністю до гіпоксії і роль оксиду азоту / Н. М. Кургалюк, О. В. Інкрет, В. К. Рибальченко та ін. // Доповіді НАНУ. - 2002. - № 2. - С. 182-188.

2. Бабаджанова М. А. Функциональные свойства мультиферментного комплекса ключевых ферментов цикла Кальвина / М. А. Бабаджанова, М. А. Бакаева, М. П. Бабаджанова // Физиология растений. $-2000 .-$ Т. 47. - С. 27-36.

3. Барановский Б. А. Биоразнообразие пойменных озер Степного Приднепровья / Б. А. Барановський, Н. И. Загубиженко, Т. В. Миколайчук // Биоразнообразие и роль зооценоза в естественных и антропогенных экосистемах. Матер. II Междунар. научн. конф. - Д. : ДНУ, 2003. C. 25-26.

4. Бессонова В. П. Практикум по физиологии растений. - Д., ДНУ, 2006. - 316 с.

5. Василюк О. М. Загальні механізми адаптації рослин в умовах антропогенного навантаження / О. М. Василюк, Н. П. Коцюбинская, Т. Р. Левенець // Екологія кризових регіонів України. Тези доп. Міжнар. конф. - Д., 2001. - С. 56.

6. Василюк О. М. Вплив ксенобіотиків на ферменти переамінування у $C-4$ рослин на фоні дії регулятора росту агростимулін / О. М. Василюк, Н. П. Коцюбинська // Фізіологія рослин та екологія. Матер. Всеукр. науково-практ. конф. - Д., 2003. - С. 35-36.

7. Василюк О. М. Ферменти азотного метаболізму деревних рослин як маркери екологічного стану навколишнього середовища // Промислова ботаніка: стан та перспективи розвитку. Матер. V Міжнар. наук. конф. - Донецьк : Цифрова типографія, 2007. - С. 75-76.

8. Василюк О. М. Вплив регуляторів росту на активність ферментів переамінування в листі та коренях Salix alba L. / О. М. Василюк, П. В. Гриценко // Вісник Дніпропетр. ун-ту. Біологія. Екологія. -2008 . - Вип. 16, т. 1. - С. 34 40.

9. Василюк О. М. Фізіолого-біохімічні показники стану деревних рослин в умовах промислових зон степового Придніпров'я / О. М. Василюк, А. Ф. Кулік // Екологічні питання співіснування: людина - рослина. Матер. Всеукр. науково-практ. конф. - Д. : Центр екологічноі освіти та інформації, 2009. - С. 127-132.

10. Винниченко А. Н. Эколого-физиологические механизмы адаптации растений к стрессам антропогенного происхождения / А. Н. Винниченко, Н. П. Коцюбинская // Устойчивое развитие: загрязнение окружающей среды и безопасность. Тез. Междунар. конф. - Д. : ДГУ, 1995. T. 2. - C. 5.

11. Распределение тяжелых металлов в органах проростков / А. Н. Винниченко, Е. М. Василюк, В. С. Бильчук, А. Н. Мисюра // Биоиндикация и биомониторинг - теоретические вопросы и практическое внедрение. - Запорожье : Запорожский гос. ун-т, 1996. - С. 75-78.

12. Влияние гербицидов на активность и полиморфизм аспартатаминотрансферазы / А. Н. Винниченко, Н. П. Коцюбинская, В. С. Бильчук и др. // Бюлл. ин-та кукурузы. - 1995. - № 80. C. $14-19$.

13. Дари лісів / Ю. Я. Єлін, М. Я. Зерова, В. І. Лушпа, С. І. Шаброва. - К. : Урожай, 1979. - 255 с.

14. Дзюбак О. І. Вплив хлоридного засолення на морфометричні та біохімічні показники рослин у динаміці росту та розвитку / О. І. Дзюбак, О. М. Василюк // Фундаментальні та прикладні дослідження в біології. Матер. I Міжнар. наук. конф. - Т. 2. - Донецьк : Вебер, 2009. - С. 231-232.

15. Косаковская И. В. Стрессовые белки растений. - К. : Фітосоціоцентр, 2008. - 151 с.

16. Воздействие тяжелых металлов, радиации и гербицидов на функциональное состояние растений в агрофитоценозах / Н. П. Коцюбинская, В. С. Бильчук, Е. М. Василюк, С. И. Старикова // Фундаментальные проблемы окружающей среды. Биоэкология. Тез. докл. междунар. конф. Томск : Томск. ун-т, 1995. - С. 132. 
17. Кретович В. Л. Усвоение и метаболизм азота у растений. - М. : Наука, 1987. - 486 с.

18. Кулик А. Ф. Микробоценоз и устойчивость лесных биогеоценозов // Екологія та ноосферологія. - 1999. - № 3-4. - С. 145-147.

19. Кулік А. Ф. Активність інвертази та уреази у грунтах лісових біогеоценозів Присамар'я / А. Ф. Кулік, О. М. Василюк, О. В. Рошка // Вісник Дніпропетр. ун-ту. Біологія. Екологія. 2007. - T. 1. - C. 77-81.

20. Кулік А. Ф. Активність інвертази та уреази в грунтах природних біогеоценозів / А. Ф. Кулік, О. М. Василюк // Питання степового лісознавства та лісової рекультивації земель. - Д. : ДНУ, 2010. - C. 28-30.

21. Кулик А. Ф. Микробиологический мониторинг экологического состояния почво-грунтов рекультивированных земель Западного Донбасса // Екологія кризових регіонів України. Тези доп. Міжнар. конф. - Д. : ДНУ, 2001. - С. 12.

22. Лакин Г. Ф. Биометрия. - М. : Высшая школа, 1990. - 293 с.

23. Методы биохимического анализа растений / Под ред. В. В. Полевого, Г. Б. Максимова. - Л. : Изд-во Ленингр. ун-та, 1978. - 192 с.

24. Функціональні зміни у рослин в умовах антропогенного впливу / Н. П. Коцюбинська, В. С. Більчук, О. А. Папета, Л. В. Шупранова, О. М. Василюк // Навколишнє середовище і здоров’я. Тези доп. міжнар. конф. - Чернівці : ЧДУ, 1993. - С. 142.

25. Экспрессия одноцепочечной цепи антитела к аспартатаминотрансферазе $\mathrm{P}_{2}$ в трансгенных растениях табака / В. Л. Метт, В. А. Метт, Д. Ч. Сонг, П. Х. С. Рейнолдс // Физиология растений. $-2000 .-$ T. 47. - С. 27-36.

26. Bilchuk V. S. Identification of the lysine maise forms according to aspsrtate aminotransferase features / V. S. Bilchuk, N. P. Kotzubinskaya, Y. V. Donchenko // J. of Celluar Biochem. - 1990. Vol. 14 E. - P. 275.

27. Headley C. L. Factors influencing alanin aminotransferase activity in leaves of Lalium temulenlum L. / C. L. Headley, J. L. Standart // Exp. Botany. - 1972. - Vol. 23. - P. 409-423.

28. The stress proteins in the adaptation plants to the invironment anthropogenic condition / N. Kotzubinskaya, A. Vinnichehko,V. Bilchuk et al. // Abs. 23th FEBS Meeting of the European Biochemical Sociaties. - Basel, Switzerland, 1995. - NR 61.8. - P. 315.

29. Monteira A. M. Activities of transaminases, anylases and proteases during endosperm degradation on normal and opaque-2 Zea mays L. / A. M. Monteira, J. Metivier, C. V. Maya // Anals of Botany.1980. - Vol. 52. - P. 535-541.

30. Vinnichenko A. N. Nitrogen metabolism enzymes and serine protease ingibitors of high lysine maize / A. N. Vinnichenko, N. P. Kotzubinskaya, V. S. Bilchuk // Abs. XIX FEBS meeting. - Roma, 1989. P. 196.

31. Pilet P. E. The regulation of activity aspartate aminotransferase in senescent root cekkes of lens culigris // Experientia. - 1971. - Vol. 27. - P. 880.

32. Scandalios J. G. Oxidative stress: Molecular perception and transduction of signals triggering antioxidant gene defenses // Brar j. Med. Res. - 2005. - Vol. 38, N 7. - P. 995-1014.

33. The primary structure of aspartate aminotransatrase from pig heart muscle / S. Doonan., M. J. Doonan, R. Hanford et al. // Biochem. J. - 1975. - Vol. 149. - P. 497-506.

34. Vasilyuk O. M. Aspartate aminotransferase activity in Zea maize shoots under the cesium ions influense / O. M. Vasilyuk, A. F. Kulik // Вісник Запорізького ун-ту. - Запоріжжя, 2008. - № 1. C. 238.

35. Vasilyuk O. M. Physiological and biochemical parameters of plants as markers of a condition of environment / O. M. Vasilyuk, O. I. Dzyubak // Фундаментальні та прикладні дослідження в біології. Матер. I Міжнар. конф. - Т. 2. - Донецьк : Вебер, 2009. - С. 348-349.

Надійшла до редколегії 11.01.2011 